\title{
First Report of Occurrence of Rust in South Gujarat, India
}

\author{
A. J. Deshmukh ${ }^{1 *}$, Pushpendra Singh ${ }^{1}$, V. P. Prajapati ${ }^{1}$ and Brijesh Pate ${ }^{2}$
}

${ }^{1}$ Dept of Plant Pathology, College of Agriculture, NAU, Waghai, Gujarat (394 730), India

${ }^{2} \mathrm{Hill}$ millet research station, NAU,Waghai, Gujarat (394 730), India

\section{Corresponding Author}

A. J. Deshmukh

e-mail: amol_deshmukhnau@yahoo.co.in

\section{Article History}

Article ID: IJEP0249

Received in $16^{\text {th }}$ March, 2018

Received in revised form $11^{\text {th }}$ April, 2018

Accepted in final form $20^{\text {th }}$ April, 2018

\begin{abstract}
The incidence of rust (Uromyces sp.) on chickpea cv. GG-2 was first noticed during the rabi-2018 in south Gujarat, India. Symptoms were observed initially just after flowering stage on the lower leaves and consequently on upper leaves as small, round or oval, light brown to dark brown pustules, which coalesces later to form bigger pustules covering with a ring of small pustules under field conditions.The disease severity ranged from 24 to $30 \%$. The urediospores were observed to be yellowish to brownish in colour. The shape of urediospores was observed as globose, echinulate, measuring 18-26 $\mu \mathrm{m}$ in diameter. Based on the symptomatology and morphological characters of the uredospores, the pathogen was identified as Uromyces sp. This is thought to be the first report of the pathogen causing chickpea rust from south Gujarat, India.
\end{abstract}

Keywords: Chickpea, rust, Uromyces sp.

\section{Introduction}

Chickpea (Cicer arietinum L.) is one of the most important pulse crops of India. The crop is grown on an average area of about 16401 ha per year with the average productivity of 1250 kg grain yield per ha in Dang District of south Gujarat (Dobariya et al., 2016). Being one of the major and important Rabi crops of Dang district, there is a need to resolve the constraint of higher production of this crop in the Dang. More than 50 pathogens have been reported to affect chickpea which includes both soil and air borne pathogens over the globe. The crop was found to be affected mainly with common soil borne diseases such as wilt from Dang district. But in the recent past, rabi season-2018. The incidence of chickpea rust was first time observed in a chickpea cultivar GG-2 at Hill millet research station, Navsari agricultural University, Waghai and hence present study was undertaken to study the symptomatology, morphology and per cent disease occurrence of chickpea rust in cultivar GG-2 of chickpea in present area.

\section{Materials and Methods}

\subsection{Symptomatology}

The severely affected diseased field of chickpea (GG-2) was observed carefully for the symptoms and signs produced by the rust pathogen on different plant parts from initiation stage of the infection to harvest stage. All the symptoms observed were recorded carefully and presented further in detail.

\subsection{Morphology and identification of the inciting pathogen}

Collection of diseased plant specimen was done in order to study the morphology and identification of inciting plant pathogen. The fresh infected leaves were subjected to microscopic examination. The morphological characters of the fungal spore or structure viz., length and diameter were measured under low power magnification using stage and ocular micrometre. The pathogen was then identified up to genus with the help of comparison of observed microscopic morphological characters with those given in earlier literature.

\subsection{Per cent disease incidence}

The severity of chickpea rust was recorded from three diseased plots of GG-2 by adopting 0-5 scale (Hiremath et al., 1987) with observing 10 leaves in 10 plants plot ${ }^{-1}$ from three sites (Table 1).

Further this scale was converted to per cent disease intensity (PDI) using the formula given by Wheeler (1969).

$P D I=\frac{\text { Sum } \text { of numerical disease ratings }}{\text { No. of plants observed } \times \text { Maximum disease grade }} \times 100$

\section{Results and Discussion}

\subsection{Symptomatology}

Rust symptoms (Figure 1 and 2) were found to be appearing initially just after the flowering stage on the lower leaves and consequently on upper leaves as a small, round or oval, 


\begin{tabular}{|c|c|}
\hline \multicolumn{2}{|l|}{ Table 1} \\
\hline $\begin{array}{l}\text { Rating } \\
\text { value }\end{array}$ & Description \\
\hline 0 & Leaves free from infection \\
\hline 1 & $\begin{array}{l}\text { Small brown raised rust pustules covering }<5 \% \\
\text { leaf area }\end{array}$ \\
\hline 2 & $\begin{array}{l}\text { Small brown raised rust pustules covering } 5.1 \text { to } \\
10 \% \text { leaf area }\end{array}$ \\
\hline 3 & $\begin{array}{l}\text { Small brown raised rust pustules join together } \\
\text { covering } 10.1 \text { to } 25 \% \text { leaf area }\end{array}$ \\
\hline 4 & $\begin{array}{l}\text { Small brown raised rust pustules join together } \\
\text { to form irregular patches covering } 25.1 \text { to } 50 \% \\
\text { leaf area }\end{array}$ \\
\hline 5 & $\begin{array}{l}\text { Small brown raised rust pustules join together } \\
\text { to form irregular patches covering more than } \\
50 \% \text { leaf area. }\end{array}$ \\
\hline
\end{tabular}

light brown to dark brown pustules. The numbers of small pustules were coalesces later to form bigger pustules. The bigger pustules were found to be covered with a ring of small pustules at later stage under field conditions. The severity was found to increase further covering whole leaf area of affected plants as the crop progresses towards harvest stage. Pustules have also been observed occasionally on stems and pods at crop harvest stage. More or less similar types of symptoms of chickpea rust were also observed and described earlier (Deshmukh et al., 2010; Nargund et al., 2011).
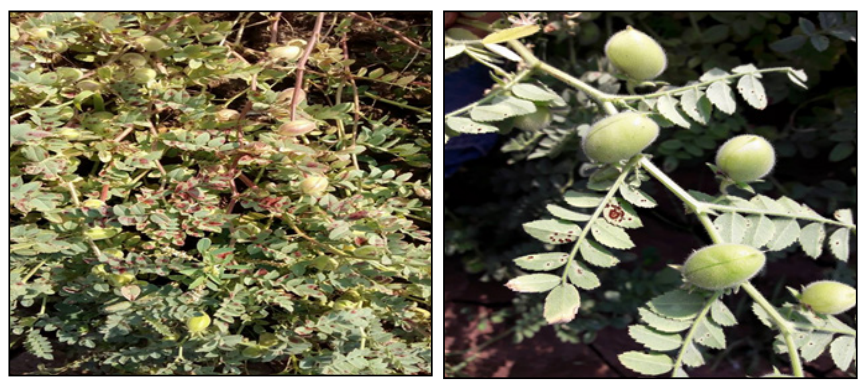

Figure 1 and 2: Field view and close view of chickpea rust on cultivar GG-2

\subsection{Morphology of the pathogen}

The microscopic examination of fresh infected sample yields the presence of uredospores and teliospores (Figure 3 and 4) under low power magnification. The uredospores were observed to beglobose to subglobose, loosely echinulated structure having 18-26 $\mu$ in diameter. These are found to yellowish-brown in colour having thick episporewith four to eight germ pores. The teliospores were found to be resembled with uredospore but were found to darker brown in colour. These were observed to be ovate or angular with a roundish apex having warty or roughened wall with thick epispore and a short, hyaline pedicel. Only single germ pore was seen in the
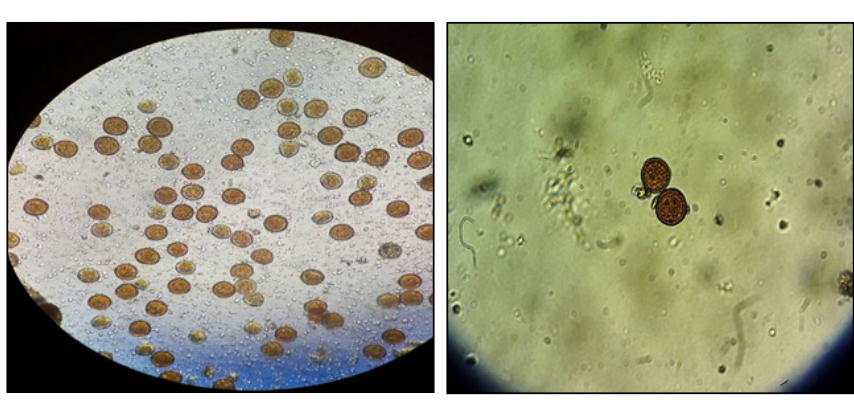

Figure 3 and 4: Microscopic structures: Uredospore and Teliospore

teliospore as compared to 4 to 8 germ pores in uredospores.

More or less similar types of morphological characters of chickpea rust pathogen were observed and described earlier (Emeran et al., 2005; Keshavarz et al., 2010; Deshmukh et al., 2010; Nargund et al., 2011).Thus, the pathogen was identified and confirmed here as Uromycessp. causing chickpea rust in this area.

\subsection{Per cent disease incidence}

The results (Table 2 ) on the study of per cent disease incidence of chickpea rust reported that the two cultivars viz., GG-2 (27.33\%) was found severely infected with the rust disease.

The occurrence of rust (Uromycesciceris-arietini) on chickpea cv. Digvijay was first time noticed in western Maharashtra, India, during the 2009 rabi season. The disease severity ranged from 10 to $15 \%$ (Deshmukh et al., 2010). Moreover, Nargund et al. (2011) surveyed and reported that during rabi- 2009-10 season chickpea suffered heavily due to rust caused by $U$. cicerisarietini, the severity of the disease was to such an extent that all the genotypes grown at Main Agriculture Research

Table 2: PDI of chickpea rust on cultivar GG-2 during rabi2018 at Hill millet Research Farm, NAU,Waghai

\begin{tabular}{lc}
\hline Plot No. & PDI (\%) \\
\hline 1 & 28.00 \\
2 & 24.00 \\
3 & 30.00 \\
Mean & 27.33 \\
\hline
\end{tabular}

Station, Dharwad encompassing germplasm lines, ICRISAT collections, segregating populations and $F_{1}$ of several crosses showed highly susceptible reaction to rust.

The disease incidence observed here was for first time and was not reported earlier from the south Gujarat area. Moreover, it can also be foretold that the chickpea rust is sporadic in nature in the confined area as it was first time occurred in recent past and was not even noticed earlier. Furthermore late stage occurrence of disease gave minor significance to disease in reducing crop yield.

\section{Conclusion}

The incidence of rust (Uromyces sp.) on chickpea cv. GG-2 
observed here was first report from south Gujarat, India. Symptoms were observed in late stage i.e. flowering stage of crop. Both the upper and lower leaves were affected but disease initiation was started on lower leaf. Small to big pustules formation on the lower leaves followed by consequent upper leaves are the typical symptoms of the disease. Uromyces sp. was found to be the chickpea rust causing pathogen on the basis of morphological character study through microscopic observation. The disease severity ranged from 24 to $30 \%$ at hill millet research farm, NAU, Waghai.

\section{References}

Deshmukh, G.P., Pawar, K.B., Harer, P.N., 2010. Occurrence of rust on chickpea in Western Maharashtra. Journal of Maharashtra Agricultural Universities 35, 485-486

Dobariya, J.B., Thesiya, N.M., Zinzala, V.J., Aklade, S.A., 2016. Cropping Pattern in Tribal Area of Dang District. Journal of Krishi Vigyan 5, 19-22.

Emeran, A.A., Sillero, J.C., Niks, R.E., Rubiales, D., 2005.
Infection structures of host specialized isolates of Uromycesviciae-fabae and of other species of Uromyces infecting leguminous crops. Plant Disease 89, 17-22.

Hiremath, P.C., Reddy, B.M.R., Deshpande, V.P., Hegde, R.K., 1987. Occurrence of rust epidemic on Bengal gram in Karnataka. Current Research of Agricultural University, Bangalore 16, 171-172.

Keshavarz, S.A., Moosavi, J., Minassian, V., Torabi, M., 2010. Morphology and host range of Uromycesviciae - fabae, the causal agent of faba rust. Iranian Journal of Plant Pathology 46, 89-91.

Nargund, V.B., Benagi, V.I., Salimath, P.M., Rao, M.S.L., Nagaraju, P., Basavarajappa, M.P., 2011. Effect of climate change in relation to severity of chickpea rust in northern Karnataka. National Symposium on Integrated Disease Management Strategies in Relation to Climate Change in South India. October 14-15, 2011, Dharwad, Karnataka. Wheeler, B.E.J., 1969. An Introduction to Plant Disease. John Willey and Sons Ltd., London, 301. 